\title{
Environmental problems and Geographic education. A case study: Learning about the climate and landscape in Ontinyent (Spain)
}

\author{
Benito Campo-Pais (10 ${ }^{1 凶}$, Antonio José Morales-Hernández ${ }^{1}$, Álvaro Morote-Seguido ${ }^{1}$ \& \\ Xosé Manuel Souto-González (i) ${ }^{1 凶}$
}

Cultural perceptions of the environment bring us back to elements and factors guided by "natural" cause-effect principles. It seems that academic education has had little effect on the manner and results of learning about changes in the local landscape, especially as regards rational explanations. There is considerable difficulty relating academic concepts about the climate to transformations in the environmental landscape. Teaching tasks are mediatized due to the use of rigorous and precise concepts which facilitate functional and satisfactory learning. This is the objective of the research this article aims to undertake, for which we have chosen the case of Ontinyent (Spain). This research will include two parts: the first aims to identify problems in geographical education of the climate, and the second applies to didactic suggestions for improvement. Methodologically, this study involves qualitative, non-experimental, research-oriented toward change, which purports to understand the educational reality. Our sample included a total of 431 students. Moreover, a semi-structured interview, conducted with teachers in schools and universities in Ontinyent, was organized. Fourteen teachers were interviewed, including two who participated as research professors in the action-research method. The study revealed that students' conceptual and stereotypical errors, in the different educational stages, vary according to the type (climate, weather, climate change, landscape) and stage (Primary, Secondary, University). They are persistent and continuous, given that they are repeated and appear anchored in the ideas and knowledge development of students regarding the problems and the study of the climate throughout their education.

\footnotetext{
${ }^{1}$ University of Valencia, Valencia, Spain. ${ }^{凶}$ email: Benito.Campo@uv.es; xose.manuel.souto@uv.es
} 
“The spring, the summer,

The childing autumn, angry winter, change

Their wonted liveries, and the mazed world,

By their increase, now knows not which is which:

And this same progeny of evils comes

From our debate, from our dissension"

(W. Shakespeare, A Midsummer Night's Dream, cited in Kitcher and Fox, 2019)

\section{Introduction}

raditionally, school-taught geography has focused on studying the relationships between physical and cultural factors in the organization of the environment (Capel, 1981, 1984; Graves, 1985). Climate change and the environmental impact are two representative examples that have had an impact on how the research group Socials ${ }^{1}$ has planned educational activities.

In this vein, the sixth Global Environment Outlook report (GEO 6) declared that climate change is a matter of priority that affects both human (including human health) and natural systems (the air, biological diversity, freshwater, the oceans, and the earth) and alters the complex interactions between these systems (UNEP, 2019, p. 10).

Furthermore, the 2030 Agenda for Sustainable Development expresses, through Sustainable Development Goal 13 (SDG 13), the need to "take urgent action to combat climate change and its impacts" (United Nations, 2015, p. 16). All of this leads us to reflect on the way in which we learn about and understand the concept of climate and its impact on the landscape, and vice versa, in order to take measures, as a critical and active citizen, which could reverse the current emergency situation facing the planet's climate.

Within the group Socials (University of Valencia, Spain), we are developing a line of didactic research related to socioenvironmental education to analyze the obstacles which hinder learning about the climate and landscape in an academic setting. This includes the following: (1) The lack of an interdisciplinary approach to understand the impact on socio-ecological systems from a glocal perspective; (2) The disconnection between scholarly academic knowledge related to the climate/landscape and the reality experienced by students, which allow for geographic conceptualization and an understanding of the world from school-taught geography (Cavalcanti, 2017); (3) The absence of analysis of the influence of social representations (Moscovici, 1961) on the perception of the environment (Reigota, 2001) related to the interaction between climate and landscape; (4) The need to boost active participation (Hart, 1993) in order to implement strategies and measures related to climate change mitigation and adaptation; and (5) The accuracy of using active territoriality (Dematteis and Governa, 2005) to create emotional links with the territory we must manage (Morales, Santana and Sánchez, 2017), due to its particular impact on climate and landscape factors.

All of this leads us to re-evaluate the importance of analyzing cultural perceptions of the environment to determine the factors which have an impact on environmental transformation, starting from the paradigm Education for Eco-Social Transformation. The aim is to encourage the inclusion thereof in the academic curriculum (González, 2018). This is a line of study we have already tackled through the analysis of the trialectics of spatiality, where we reconsidered the Piaget taxonomy of lived, objective, and conceived spaces (Hannoun, 1977). We aimed to further our understanding of space through lived emotions, the cultural perceptions which create spatial stereotypes, and the conceived space, a result of the actions taken by political and economic leaders in the country (Souto, 2016, 2018a). This conceptual modification helped us understand the environment as a process of intellectual construction, like a reflection of a physical reality conceived with emotions and social filters. In other words, this is coherent with what we consider in our research proposal.

\section{Our approach to the problem}

Local geographical studies are methodologically similar to what are known as case studies in educational research. To this effect, it is worthwhile recalling that a local case is specific, but it is not unique or unrepeatable. That is to say, there are aspects particular to the social and territorial context, but the explanatory factors refer us to theories that have been developed around other comparative analyses. In this vein, the work we are presenting here, as a case study of climate and landscape education in Ontinyent (Spain), answers three basic questions which outline the problem.

Firstly, what is the role of the academic system in explaining everyday issues? If climate change and the perception of changes in the landscape are of social concern, we must specify whether the academic system should codify aspects of these expectations in a conceptual corpus. This can be done through a series of educational activities and by seeking answers to events that may be communicated with explanations in a public sphere. This will be the main objective of this study.

Secondly, we wonder what specific disciplinary knowledge can contribute? In the case of geography, due to its interdisciplinary links, it will be useful to determine its impact on academic knowledge and, consequently, the construction of a public opinion regarding everyday issues. How can an understanding of geography affect the development of a critical theory which questions the practical meaning of everyday life?

Finally, a significant contribution to this study: what conclusions can we draw from the social representations of spontaneous knowledge in developing social arguments? We want to know to what extent representations of daily practicality present an obstacle to developing independent knowledge and thus render conceptual disciplinary knowledge useful for arguing in public opinion debates influencing common sense and determining our everyday practicality. We wanted to exemplify this with ideas provided by students and teachers from schools in the region.

When looking at the relationships between stages, from global phenomena to local measures with eco-geographical dynamics and where anthropogenic activities are included as explanatory factors, school and university students' ideas about the climate and the lived and conceived landscape do not tend to be included in a subjective way. This fact contradicts the definition itself of the landscape set out in the European Landscape Convention, by not taking into account the territorial perception of the population (Council of Europe, 2000).

The central idea of our line of research points to using students' personal and social perceptions as a starting point to develop basic knowledge about the climate and landscape. We question spontaneous concepts to explain the landscape in terms of the climate and create a certain environment (microclimate, evapotranspiration, sunlight...).

In this vein, students taking the Research in Social Science Didactics: Geography postgraduate programs (University of Valencia) have produced several master's and Doctoral Theses 
which deal with the existing relationship between social representations and environmental education ${ }^{2}$. Some of this research is related to the EcoRiba ${ }^{3}$ project, with the aim of understanding the importance of linking this didactic research to integral education about the local environment, in order to promote more sustainable and supportive interactions both in a local and global setting (Morales and García, 2016; Morales, 2017; Morales, 2018). It is a way of integrating academic studies into social and civic renown, an academic construction of an educational public space for the local community.

\section{The research context}

Studies about "marginalised students" 4 as examples of the realities of academic failure, but also of second chances, present arguments about what happens in the teaching and thus the didactics of geography. Analyzing this set of school students provides evidence linking failure with teachers' and students' personal narratives to understand what is concealed (Campo, Ciscar, and Souto, 2014; García Rubio and Souto, 2020). As such, it was possible to carry out an assessment, using social representations, of academic knowledge which facilitates improvement options at different educational stages, including the experiences of marginalized students (Campo, 2014). These representations also challenge academic traditions and routines, presenting obstacles and causing difficulties teaching and learning geography (Canet et al., 2018; Campo et al., 2019). These studies represent the instruction and methodological arguments that are part of the rational and personal reasons for taking on this research: learning difficulties at school, social representations in educational research of geography didactics, and the question of innovation as a requirement for educational improvement.

We have pinpointed these principles for a research topic. Learning about the climate and landscape is fundamental for students to understand environmental changes and problems and, moreover, is part of geography didactics both in basic education (Tonda and Sebastiá, 2003; Jaén and Barbudo, 2010; García de la Vega, 2014; Martínez and López, 2016; Olcina, 2017; Martínez and Olcina, 2019), and in the work of students training to become teachers (Valbuena and Valverde, 2006; Boon, 2014; Souto, 2018a; Morote et al., 2019) who highlight the dilemmas and perceptions of geography or climate change (González and Maldonado, 2014; Chang and Pascua, 2016). In our case, we are mainly concerned with observing what is happening in classrooms. Students make explanations about climate problems which are full of mistakes and stereotypes produced by the trivialization of some scientific concepts shared by the mass media (Olcina and Martín, 1999; Martín-Vide, 2009). In order to analyze students' education about the climate and landscape, we must identify teaching practices (Souto, 2013, 2018a) and reveal what students know. In both cases, we are guided by various studies focused on conceptions, ideas, and representations (Gil, 1994; García Pérez, 2002, 2004; Kindelan, 2013; Bajo, 2016; Santana, 2019; García-Monteagudo, 2019) which, stemming from research and interest in the psychology of learning, aim to understand student mistakes and make constructive suggestions based on models focused on student learning. This starts with their existing knowledge, moving on to what students have been taught, and finally observing the impact of the media on their education. In this way, theoretical tenets of social representations will allow us to interpret what is happening, based on referential systems and enabling categories that classify contexts, phenomena, or individuals (Jodelet, 1991). We use these educational research theories with the pertinent epistemological awareness (Castorina and Barreiro, 2012) which proves the representations observed in school geography (Souto and García, 2016) among the population as regards climate change (Heras, 2015; AlatorreFrenk et al., 2016) and the landscape (Santana et al., 2014) or among students and teachers in the practice thereof (Domingos, 2000).

This objective corresponds with a line of research ${ }^{5}$ linked to doctoral research ${ }^{6}$, which outlines its idiographic, explanatory, and applied nature (Bisquerra, 2009). First, it is idiographic due to the approach for understanding and interpreting the unique nature of school geography lessons on the climate and landscape as curricular content. Secondly, it is explanatory because it claims to clarify what is happening in teaching-learning processes. Finally, it is applied in nature because it aims to transform the conditions of didactic activities and introduce improvements in the teaching-learning process of geography using real-life experiences from schools in Ontinyent (Spain). This research will include two parts: the first aims to identify problems in geographical education of the climate, and the second applies to didactic suggestions for improvement.

In this article, we will develop the first part-assessing the topic we outlined above. Our hypothesis indicates that geography lessons about the climate, school traditions, and the mass media lead to knowledge shaped by stereotypes and conceptual mistakes which are exposed in children's education and remain present in higher education.

\section{Methodology}

This study involves qualitative, non-experimental, researchoriented toward change, which purports to understand the educational reality. As such, an open and mixed design is most suitable, which adapts to the knowledge observed during the study. This justifies the analytical study we propose for this research. We selected the case study (Stake, 1999, Álvarez and San Fabián, 2012) as a way of analyzing how students in Ontinyent (Valencia) learn about the region's climate and landscape. Given the study's characteristics and the objective of making the quantity of information manageable and systematizing the analysis (Goetz and Lecompte, 1988; Miles and Huberman, 1994; Rodríguez et al., 1996; Rodríguez et al., 2005) we have used a combination of quantitative techniques, which make statistical analysis possible (Gil, 2003), and qualitative techniques, which facilitate content analysis, for the data analysis. This combination of techniques is used in case studies to further explore explanations for the phenomena analyzed, with the aim of making the quantity of information manageable (Bisquerra, 2009).

It is worthwhile outlining the sample in context for assessment purposes. The sampling technique used is non-probabilistic for convenience and accessibility (Bisquerra, 2009; Otzen and Manterola, 2017). We chose the municipality of Ontinyent due to adjustment reasons and opportunity criteria. On the one hand, the population of Ontinyent assures a sample size that is representative of a concrete population: the innovation program ${ }^{7}$ provided access to school and university settings in this municipality which has a population of $35,534^{8}$ (2016) and boasts educational centers across the different educational stages: Kindergarten, Primary, Secondary, and University. In other words, we can carry out a transversal study of children's education about the climate throughout the different educational stages, with different chronological ages, at the same time and encompassing the entire school and university education of one person. On the other hand, Ontinyent, as shown in Fig. 1 is a municipality in the Community of Valencia (Spain) with specific climatic conditions due to its location 47 kilometers from the Mediterranean Sea. It has a typical Mediterranean climate or, according to the Koppen classification, a semi-arid cold climate with mild winters and hot summers (Guerra, 2018). 


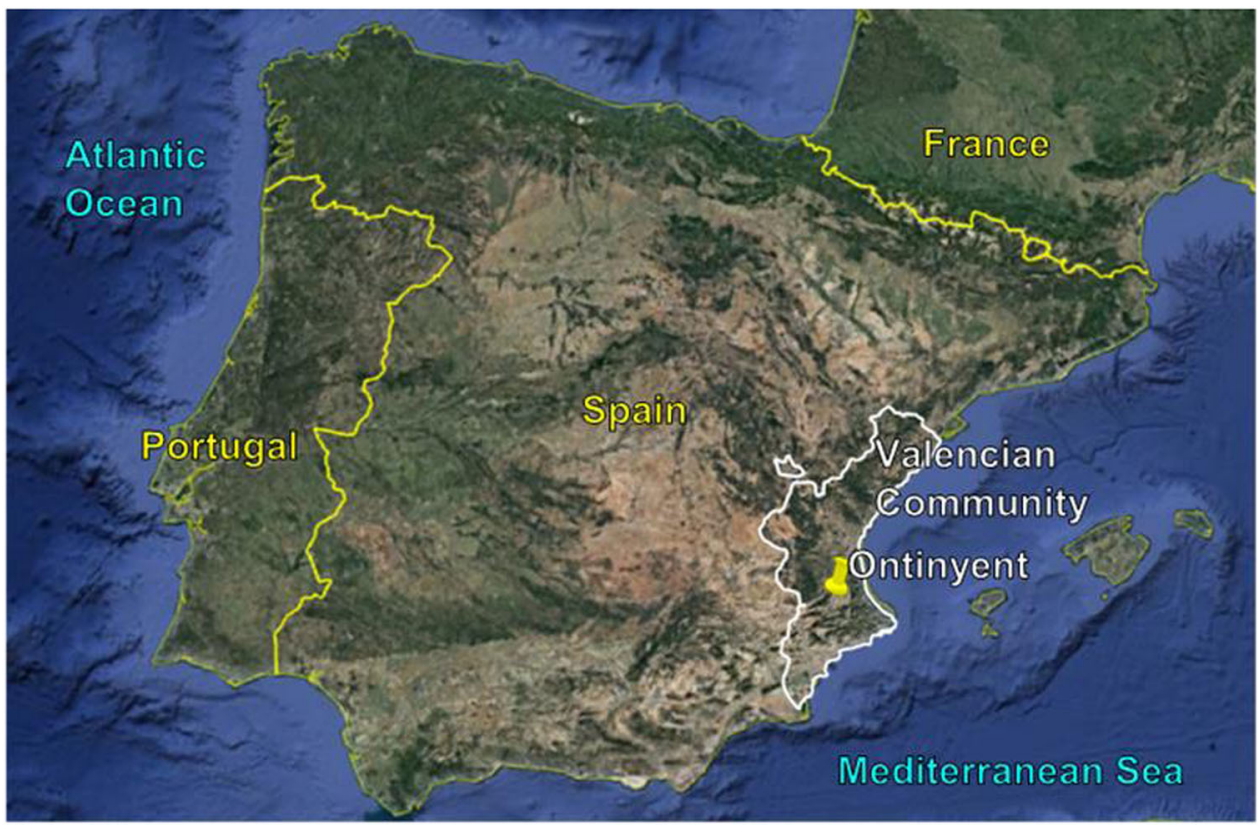

Fig. 1 Ontinyent location map. Ontinyent is located within Valencian Community (Spain). Self-elaborated map based on Google Earth data.

Table 1 Study population sample relation.

\begin{tabular}{|c|c|c|c|c|c|}
\hline \multicolumn{2}{|l|}{ Demographic references } & Total population & \multirow{2}{*}{$\begin{array}{l}\mathbf{0 - 2 4} \text { years } \\
9.344 \\
1.236 .989\end{array}$} & \multirow{2}{*}{$\begin{array}{l}\text { School population } \\
6.185 \\
976.929\end{array}$} & \multirow{2}{*}{$\begin{array}{l}\text { Confidence Interval } \mathbf{( C I )} \\
0,52 \%\end{array}$} \\
\hline Ontinye & 35.534 & & & & \\
\hline Infant school & 996 & 6 years & 363 & 202 & $4 \%$ \\
\hline Primary education & 2627 & $5^{\text {th }}-10$ years & 465 & 204 & \\
\hline Secondary and Bachelor & 2224 & $2^{\text {nd }}-14$ years & 473 & 135 & \\
\hline Total Population & 6185 & & 1413 & 633 & $3,90 \%$ \\
\hline
\end{tabular}

The relation between the municipal population (Ontinyent) and the region (Valencian Community) within the ages of 0 -24 years representative of the school and university stages of the study. The relation between the school and the university population of Ontinyent with the population participating in the study by educational stages.

During the 2015-16 academic year, between May and December 2016, we gathered data from different school classrooms in Ontinyent, including 5 Kindergartens ${ }^{9}$ and Primary Schools (4 public schools and 2 private schools with state-funded financial support), 3 Compulsory and Baccalaureate Secondary Schools ${ }^{10}$ ( 1 public school and 2 private schools with state-funded financial support) and the headquarters of the University of Valencia in Ontinyent ( 2 classes of the Teaching Diploma). In total, 202 first-year primary school pupils, 204 fifth-year primary school pupils, 135 second-year secondary school students, and 92 university students taking the Teaching Diploma participated.

As such, our sample included a total of 633 students, covering a range of the academic population, from both school and university, in Ontinyent which has a total of 6185 students $^{11}$. If we take the demographic numerical data in Table $1^{12}$ as a reference, it represents a Confidence Interval (CI) of $0.52 \%$ which indicates that the academic population in Ontinyent is representative of the academic population in the Community of Valencia. This represents a level of reliability equaling $95 \%$ of the academic population, typical of Social Sciences statistical studies (Campo and Martínez, 2017). But this does not mean that the study sample is in turn representative of the population in the Community of Valencia.
In order to define the context of academic knowledge, qualitative tools were developed. These tools are unique to research in Social Science Didactics and include a semi-structured interview and questionnaire (Banchs, 2000). These tools have been validated by experts in the fields of knowledge associated with this research (Physical Geography, Regional Geographical Analysis, Social Science Didactics and Didactics, and School Organisation) from four universities, three of which are in Spain (Seville, Alicante, and Valencia) and one in Chile (La Serena). ${ }^{13}$

Furthermore, this research draws on previous studies ${ }^{14}$, using the action-research method which puts the participating students and teachers at the heart of the study (Stenhouse, 1990; Elliot, 2000), reflecting on their own practice (Teppa, 2012). This distinctly includes the model of a research professor in the research (Stenhouse, 1975; Sancho and Hernández, 2004). In order to improve the curriculum, teachers and other professionals are in the best conditions to carry out this type of research.

The questionnaire is a versatile technique that facilitates the collection of information regarding the objectives of the research. In January and February 2016, teachers and students were asked to participate in the study, obtaining a commitment of wilfulness for this investigation. This is done through specific questions which gather specific quantifiable information for the study 
(Cohen and Manion, 1990), thus allowing for direct comparison between groups. In our case, this is a comparison between the variable of educational stages or the co-variation of students' ideas in the different educational stages when learning about the climate. Its design focuses on the evaluative considerations of a questionnaire about geography didactics (Alfageme et al., 2010) and follows the process itself for the creation of questionnaires: following the research objectives, creating a first draft of the questionnaire for assessment and validation by experts, carrying out a pilot test and delivering the final version of the questionnaire (Del Rincón et al., 1995). For the proposed analysis, we used three of the sections which make up the questionnaire: the first section, item 1, covers information sources for students about climate change; the second section, items 2 to 6 , looks at the difference between the climate and the weather; the third section, items 7 to 10, tackles the causes of climate change. The questionnaire was created based on content that appears in the textbooks used by participants, containing the same questions/items in order to maintain homogeneity among the 431 participating students, representing Primary Education (10-12 years old; 105 girls and 99 boys), Secondary Education (13-15 years old; 63 girls and 72 boys) and University (82 women and 8 men with 21-23 years old). The design covers a mixed structure of closed and open questions which appear in sections with the corresponding items.

The semi-structured interview, conducted with teachers in schools and universities in Ontinyent, is a substantial part of the research. The teachers were selected according to accessibility and interest in the research. This convenience-based option was chosen due to the possibility of being able to interview them and the relevance to the project framework on the study of the climate and landscape ${ }^{15}$. Fourteen teachers were interviewed, including two who participated as research professors in the action-research method. The questions were chosen for the study related to their ideas (Saraiva, 2007) before participating in the project and covered teacher training, methodology and practice, and their explanations of environmental problems-how they explain environmental changes in Ontinyent to their students. Ultimately, we wanted to find out what the teacher knows and what they do to help their students learn about the climate.

Of the 14 teachers, 8 are women and 6 are men. Three of them are over the age of 56,2 are between 46 and 55 years old, 6 between 36 and 45, and 3 between 25 and 35 years old. They teach in public (6), private (7), and privately managed public (1) schools. They teach at different educational levels, 1 in Kindergarten, 2 in Primary, 9 in Secondary School, and 2 at Baccalaureate level. They teach different subjects: 2 teach Social Sciences, 4 teach Biology, 2 teach Physics and Chemistry, 1 teaches Mathematics, 1 teaches Language and Literature, 1 teaches Social Integration, 1 teaches Administration and 1 teaches Kindergarten.

\section{Results and data analysis}

The data gathered using the questionnaire and interviews are shown, in a quantitative setting, through the already processed conversion into percentages of the participants' responses per educational stage. The qualitative data has been categorized in line with the desired objectives.

Students' perception of climate and landscape. In the first section of the questionnaire, related to the hypothesis and objectives of the study, we wanted to know what the students' favorite source of news on climate change was in order to analyze the trends among students regarding the information they obtain about climate change in the communication society, and the

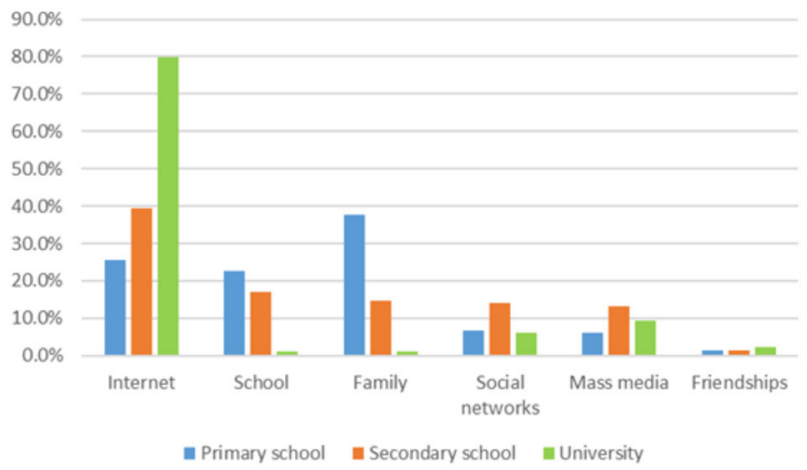

Fig. 2 Student preferred sources of news to stay updated on climate change. The bars represent the percentage. The bars represent the percentage in each educational stage.

impact on their academic knowledge (Souto, 2011). The items in this section questioned the participants about where they get information on climate change, establishing an order of preference. In order to understand what information, they get and the extent to which they receive it from the sources mentioned, we asked a multiple-choice question, the percentages of which established a percentage median of the students' priorities per educational stage. The data were quantified using a statistical median of the participants' responses per stage, reflecting the order of importance of the sources they selected in the first step. We differentiated online social networks from the internet, due to their renown and growth. Although the first requires the second, we distinguished that the essential use and function of social networks is communication between people who are active in social relationships, while the internet is a source of information with multiple uses and possibilities. Thereafter, we will detail the number of students who chose each source as their top source and the percentage of the sample. As such, as shown in Fig. 2, of the 423 students we can see how sources evolve from the family environment $(37.7 \%)$ in Primary School to the Internet $39.3 \%$ in Secondary School and $79.8 \%$ at University). We also observe that social networks are used more in Secondary School than at any other educational stage.

When analyzing the data, we started with the premise that traditional information sources for learning over the last century such as school, family, friends (social relations), and the media (the press, television) have been expanded by this society of information, communication and technology and the globalization of information and news, because we are now in a network society (Castells, 2006). Surveys by official bodies about the information society in Spain and in Europe (Eurostat, 2016) show that in 2016 95.2\% of students in Spain used the internet, 58.8\% used it every day, and $25.7 \%$ almost every day for between one and three hours. Among those over the age of 15, around $90 \%$ used the internet for e-mail and social networks. The data obtained allowed us to qualify these figures, which are reduced into percentages about more generic sectors. In this way, we established four large categories of information sources that have an impact on knowledge: school, family, the media (Internet, television, and the press), and social relations (friends and networks).

The trend shift towards the media as an information source for students was confirmed. This preference, especially from secondary school onwards, corresponds with the exponential trend for the use of the media by society. However, this suggests a problem and a risk for learning about the climate as it is subject to errors and stereotypes. The liquid modernity we live in comprises the transience, use, and access to a large quantity of data. From 
the perspective of cognitive psychology and as proven, people find it difficult to retain more than seven units of information. When building our knowledge, quality is more important than quantity. This liquid society produces a series of habits that make it difficult to learn geography (Sebastiá and Tonda, 2017). The need for information to learn collides with the sheer quantity of data available which spreads on technological motorways and platforms, motorways of information in the informational technological revolution. The so-called technological revolution hangs over new informative engineering like a cloud and is of great concern for data verification and codes of best practice (Goldenberg and Bengtsson, 2016; Wardle et al., 2018). Fake news is generated to create states of opinion about climate change (Maslin, 2019) and we have observed how these factors have a harmful impact on students' geographical literacy (Campo, 2019). In other words, data shows us that students do not look at social media from a critical perspective.

In addition to understanding the attitudes to climate and environmental knowledge, we wanted to find out what knowledge students had in relation to two main aspects of climate education: the difference between the climate and the weather, and understanding the causes of climate change. We dedicated a part of the questionnaire to these issues.

For the first aspect, we analyzed students' understanding of the differences between the climate and the weather, identifying whether they knew how to distinguish them. To do this, we provided different statements which they had to match up with climate or weather. This gave us some clues as to their cognitive level (Anderson and Krathwohl, 2001; Biggs and Tang, 2007; Granados, 2017) and what the students had learned because the act of matching up indicates subject knowledge and the identification of relationships. The data was obtained through a closed polytomous question in which they could choose which statement referred to the climate, the environment, or unsure. The statements were included in the following items of the questionnaire: item 2, "Last year, the annual average temperature in Ontinyent was $16.2^{\circ} \mathrm{C}$ " (climate); item 3 , "In the summer, the Clariano river is drier than in the winter" (climate); item 4, "The Ontinyent landscape is the Mediterranean" (climate); item 5, "It's very hot today" (weather); item 6, "Yesterday, the historical center of Ontinyent was flooded" (weather).

As shown in Fig. 3, the students in each educational stage who correctly matched the concepts with the statements were measured. In addition to the responses from students who

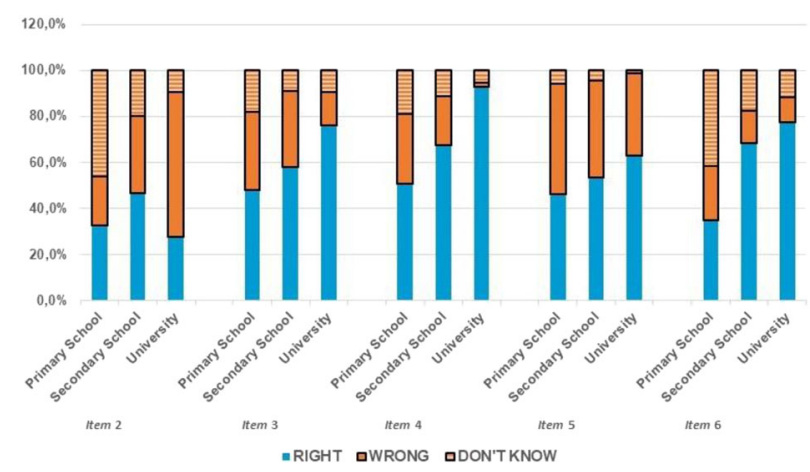

Fig. 3 Confusion regarding the usage of the terms "weather and climate". The colors of the bars represent the student's answers per item. Right answers are represented by "RIGHT". Wrong answers are represented by "WRONG". Not answered questions are represented by "DON'T KNOW". We have combined the "WRONG" and "DON'T KNOW" answers to represent the degree of confusion regarding each item at each educational stage. answered incorrectly, there were the students who indicated that they did not know.

In general, throughout the three stages, more than $25 \%$ of students matched the items up incorrectly, making mistakes with all the suggested statements, except for university students who answered item 3 correctly at a rate of $76.2 \%$, item 4 at $92.9 \%$, and item 6 at 77.4\%. The high proportion of students who answered item 2 incorrectly stands out, with at least $53.3 \%$ answering incorrectly. This percentage corresponds to the secondary school pupils. The average annual temperature was not associated with the climate and the time event "last year" confused them. Primary pupils and university students were further off-the-mark for item 2 with $67.6 \%$ and $72.6 \%$ respectively, responding incorrectly. As regards the weather, for item 5 at least $36.9 \%$ of the students surveyed (this percentage corresponds to university students) did not connect that the weather happens at a certain time while the climate is a succession of weather conditions; for item $5,53.9 \%$ of primary school pupils and $46.7 \%$ of secondary school pupils were also incorrect.

We have noted that mistakes about the concepts of climate and weather carry through from primary school to university. If we calculate the average of wrong answers to all items for students from each educational stage, the degree of confusion per participating stage is $55.5 \%$ for primary education (113 students out of 204), $41.4 \%$ for secondary education (56 students out of 135 ) and $32.32 \%$ for university (27 students out of 84 ).

Ultimately, students from all educational stages make mistakes or display a lack of knowledge about the climate and weather. This is proven by the incorrect answers to questions about the average temperature and climate (item 2), knowledge of the local climate, characteristics of the climate and its implications for the landscape (items 3 and 4), or identifying the fleeting nature of weather as the climate (item 5) or indeed other phenomena, such as a temporary flood (item 6).

Furthermore, using the questionnaire we wanted to find out if students recognized some of the causes of climate change which were presented in the questions, relating them to gas emissions or the increase in the greenhouse effect. The items were dichotomous: the participants had to select whether the statements were true or false. In line with the taxonomies established by the educational stages, the questions asked aimed to distinguish causes from events, truths from falsehoods, which is interesting given the confusion that surrounds climate change. The statements corresponded with the following items in the questionnaire: item 7, "Thanks to the greenhouse effect, we can live on Earth"; item 8, "Deforestation doesn't have an impact on climate change, it only has an impact on ground erosion"; item 9, "One of the causes of climate change is the global warming of the Earth"; item 10, "One of the causes that contribute to the process of climate change is the excessive burning of fossil fuels".

In Table 2, we note how items 8 and 9 maintain a line of progression of wrong answers in correlation with the age of students and their cognitive level per educational stage. For item

Table 2 Students' misleading about climate change causes.

\begin{tabular}{lllll} 
Causes & Primary school & $\begin{array}{l}\text { Secondary } \\
\text { education }\end{array}$ & University & Total \\
\hline Item 7 & $47 \%$ & $46,7 \%$ & $56 \%$ & $48 \%$ \\
Item 8 & $32,4 \%$ & $31,9 \%$ & $2,4 \%$ & $25,75 \%$ \\
Item 9 & $18,6 \%$ & $15,6 \%$ & $3,6 \%$ & $14,38 \%$ \\
Item 10 & $53,9 \%$ & $33,3 \%$ & $26,2 \%$ & $41,06 \%$ \\
\hline
\end{tabular}

The percentages represent the number of survey respondents who have answered wrong. The total refers to the total population $(n=431)$ that have answered wrong 
Table 3 Methodological aspects that the teachers use to explain the climate.

\begin{tabular}{lllll} 
Materials and resources & $\mathbf{n}$ & Methodology & $\mathbf{n}$ & Activities \\
\hline Textbook & 10 & Experiment environment & 3 & Brainstorming \\
Audiovisual & 7 & Investigation & 3 & Reading comprehension \\
Local data & 6 & Democratic formation & 2 & Works exhibition \\
Article/Texts & 6 & Previous ideas & 2 & Analyze data \\
Illustrations-drawings & 5 & Interactive methods & 2 & Debate \\
Web information & 5 & Cooperative Works & 2 \\
Extreme weather events & 3 & Scrum method & 1 & Tables and graphs \\
Weather map & 3 & & & 1 \\
Personal experiences & 3 & & & 1 \\
Climograms & 2 & & & 1 \\
Meteorological station & 1 & & & \\
Expert interviews & 1 & & & \\
Own presentations & 1 & & \\
\hline$n=$ number of teachers using it. & & & \\
\hline
\end{tabular}

8, 31.9\% and $32.9 \%$, and for item $9,18.6 \%$ and $15.6 \%$ of primary school and secondary school pupils responded incorrectly. Although they are almost the same, for item 8 around $32 \%$ of both groups had difficulties relating deforestation processes with the climate, as indicated by IPCC reports ${ }^{16}$. The loss of wooded areas produces a rise in carbon emissions, gases which increase the greenhouse effect (IPCC, 2013) because they are not absorbed by tree leaves and trunks. In parallel, deforestation leads to land desertification (IPCC, 2019) which hinders the processes of afforestation and reforestation. This chain explanation is an example of seeing the world and its problems in a holistic way, working on comprehensive thinking (Morin, 1990). This is more difficult to integrate with various fields of knowledge for certain levels and education.

As regards the answers to items 9 and 10, there is visible controversy. For item 9, most students recognize the link between global warming and climate change. But it is concerning that the link is not as clear in the answers to item 10 to which $54 \%$ of primary pupils, $33.3 \%$ of secondary pupils, and $26.2 \%$ of university students answered incorrectly. This data supposes that $41.06 \%$ of the surveyed population (see Table 3), in other words, 177 of 431 students between the ages of 6 and 24, do not identify the causal relationship between human activities and global warming. They do not associate the increase in burning fossil fuels with climate change (IPCC, 2014).

The item which reveals the most mistakes is item 7 . Some of the experts consulted when validating this item already indicated that it is a complex question given the origin of the gases because there are those of natural and human origin.

The analysis of the results shows us that there are different levels of confusion among students across all the educational stages to explain the relationships between physical factors (items 7 and 9), humans (items 8 and 10), and climate change. However, there is further confusion regarding the effects of human activities, which lead to deforestation and the burning of fossil fuels, on the climate and its evolution.

\section{Teachers' opinion about climate and landscape explanation}

The semi-structured interview allowed us to expand on certain aspects. Once the questions on learning had been asked and the students' ideas about the climate and landscape gathered, we wanted to define a more precise scale for analysis. In other words, we wanted to see how learning happens in real life in school classrooms. The questionnaire confirmed our hypothesis that there some conceptual problems and corresponding mistakes. The interview allowed us to dig deeper into these assumptions through teachers' disciplinary and practical training. The design of a personal interview makes it easier to repeat questions to teachers, related with concrete aspects that we had already found proof of thanks to the students' answers to the questionnaire.

For the study, four categories related to teachers' ideas were established, allowing us to elaborate coherent explanations for the analysis of students' education and the vulgar representations of climate change theories. This followed patterns shown by different authors regarding problems in learning and teaching geography, related to students and teachers (Horno, 1937; García Pérez, 2011; Liceras, 2000; Martínez and Olcina, 2019).

1. Teacher training: the academic background of the teachers interviewed is apparent in the basic statistical data we gathered. We asked them when they complete their continuous teacher training, how long it takes, at what time of day, where, and what topics they study. Given the inaccuracy of some responses, we asked them again to specify when they studied, if it was in their free time, in the evening after class, during summer courses, a Cefire course ${ }^{17}$ etc.

2. Student difficulties regarding the topic of the climate. We tried to understand what the main difficulties are which hinder the effectiveness of the explanations they bring to the subject matter and the problems they encounter when trying to explain topics to their students when teaching about the climate, climate change, and the Ontinyent landscape. To be more precise, we asked them again about knowledge gaps and the procedures and didactic learning difficulties they encounter when explaining these topics.

3. Teaching methodologies: classroom strategies. We wanted to identify what teachers' perceptions are regarding how to explain the climate in order to understand their opinion as a teacher on education about the climate and landscape, the relationship between the climate and landscape in the Clariano river landscape in the municipality of Ontinyent, and by which means they explain the problem of climate change to their students in the class. We aimed to understand how they lay out the topic with the textbook in addition to their own explanations using local data or any other means.

4. which Concepts teachers value and believe necessary to their explanations: climate, weather, climate change, minimum average temperature, night-time irradiation, sunlight, greenhouse effect, albedo effect, cold drop, and landscape. The scale is designed for them to evaluate the concept in line with their use or evaluation of it, with 0 being 
"nothing" (I don't use it or deem it useful), 1 "little", 2 "quite" and 4 "a lot".

For this article, we will present a summary of the analysis for each category in line with the questions asked and answered by the teachers.

If we analyze the results of the interviews regarding teacher training, most participants, 12 out of 14 , revealed that they completed their training outside working hours. Only two teachers answered that certain times were set aside in their work timetable for training purposes. In general, training takes place in the evening or summer, at the cost of their free time. The Cefire courses ${ }^{18}$ were the most common option for continuous training. In the end, their training was reliant on the personal availabilities of teachers who had to bear the responsibility of their training outside school hours and its costs. This infringes the challenges highlighted by different international geography partnerships and the IGU's ${ }^{19}$ declarations where they recommend geography training as a necessity for primary and secondary school teachers (De Miguel et al., 2016; De Miguel, 2017). However, it cannot be denied that nowadays, with regard to work and school organization and structure, the school system and political decisions on education result in scarce teacher training to the detriment of teachers' intentions. It is a pathway that presents too many obstacles for them to be able to commit to potential interests including didactics, innovation, and scientific knowledge about climate change. Rather it relies on the individual will and sense of responsibility of teachers, as reflected in this teacher's answer ${ }^{20}$ :

"Outside of school hours, through the completion of courses such as Cefire, reading scientific articles published in journals, watching documentaries, TV programs, etc."

As regards students and the main learning difficulties when it comes to the climate and landscape, teachers understand and outline 25 problems in total which have been categorized into five groups, and the problems which appear in Fig. 4 are broken down into percentages according to the frequency with which they appeared in teachers' answers, which was in this order: Field of Study (5 problems, 18 references), Student Characteristics (7 problems, 14 references), Didactic Materials (5 problems, 9 references), Teaching Staff (5 problems, 9 references) and School Context (3 problems, 5 references).
The problems which are identified the most and repeated most frequently are the need to experience the topic outside of the classroom and the theoretical complexity of the content, the spread of data to be used on the topic, the lack of basic education among students, and inter-disciplinary coordination. The rest of the factors highlighted by one or more teachers included the conceptual ideas and errors already held by students, the lack of continuity in the educational stages to tackle curricular topics or the objectives of the school. The teachers' answers justify the importance of taking them into account when making changes for innovation, the integration of subject matters, and working on projects and problems relevant to the student. Geography is a science explained through other sciences; these ideas, as well as those previously mentioned, were expressed by the teachers interviewed, as summarized by this teacher:

"On the one hand, the content is approached in an isolated way in some subjects and, in my opinion, it should be studied in "all" subject areas. There should be coordination among teachers, as well as continuity between stages and courses, providing a contextualised approach applied to their surroundings. Consequently, their families, the authorities and the rest of the community should participate in their studies. If, furthermore, we don't get out of the "ordinary classroom" scenario in order to observe, evaluate, analyze, apply knowledge, etc., the student ends up viewing a real problem which affects them directly as an abstract foreign concept, "something we talk about but has nothing to do with me".

Geography is a science that requires practice, so the main problem mentioned is the need for contact with the environment. It is relevant for the student to study the climate and landscape. The theoretical complexity of the topic combines with the education received by the pupil, the materials used, and the academic context, but how do teachers tackle the subject to give answers and explain the problems of school geography lessons with climate problems and the environmental consequences? (Santiago, 2008).

We will now look at how teachers organize and handle their explanations to respond to these difficulties. The methodological aspects outlined in Table 3 demonstrate the 27 aspects the

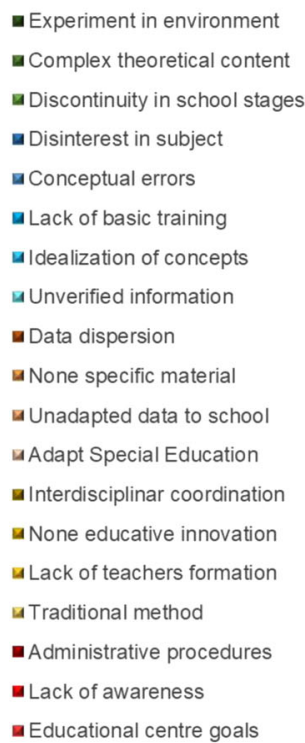

Educational centre goals

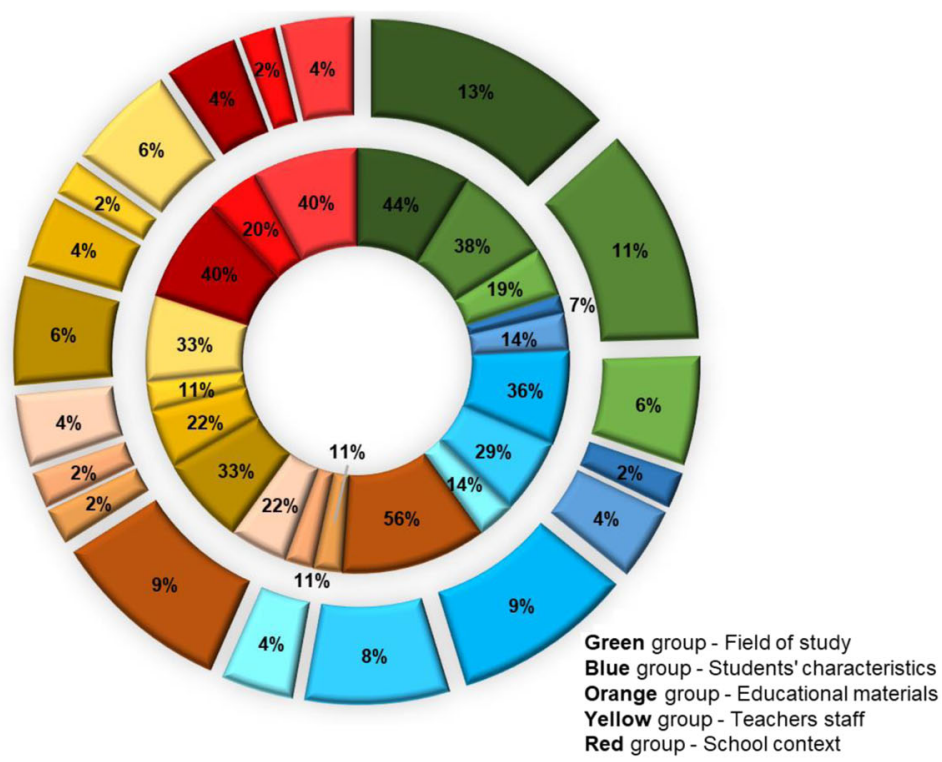

Fig. 4 Teacher's perception of climate and landscape learning difficulties. The inner ring represents the relative frequency of each difficulty within its group. The outer ring represents the absolute frequency of each difficulty within the whole array of difficulties. 
teachers associated with their teaching and the study of the climate. These factors belong to three main groups: materials and resources (13), methodologies (7), and type of activities (7). Most teachers use the textbook (10), documentaries and videos (7), local articles and data (6), illustrations, and the internet (5) for support, as a basis for the information to be studied in the classroom. In addition, but to a lesser extent, they use information about extreme weather events, climograph, or personal experiences related to the climate. The second group relates to the methods used. Environmental experimentation and research appear as the main strategy for learning alongside democratic training, the development of knowledge using previous ideas, cooperative learning, and interactive methods. Finally, the third group encompasses the activities undertaken in tandem with the methodology: brainstorming, understanding of reading materials, presenting projects, debates, and data analysis.

Some methodological aspects about resources, activities, and strategies coincide with those regularly used for teaching and learning about the climate (Romero, 2010; Martínez and López, 2016; Olcina, 2017), such as the textbook, the use of data and graphs, maps and activities for the interpretation and analysis of data. However, although there are aspects which could be included generically, there are no references to specific or innovative aspects for the study of the climate such as thematic maps, satellite images, the creation of monthly rain diagrams, constructing a laboratory, gathering data about the weather on a daily basis (Cruz, 2010) or learning based on projects or interdisciplinary projects (Rekalde and García, 2015).

The contrast between the difficulties that teachers observe among their students and the teaching they practice indicates that, without specific continuous teacher training, teachers' thoughts and intentions do not correspond with their practice to a large extent. In other words, teachers are aware of the difficulties, but they cannot utilize methods such as methodological changes and specific resources for the design of activities related to the improvement of climate study at school.

In the end, we are interested in finding out what value teachers attribute to their explanations of independent and necessary concepts to explain climate and climate change. Here we have to highlight, as can be observed in Fig. 5, the result obtained regarding the frequency of use for its evaluation. Teachers use, with a frequency of over $50 \%$, the concepts of climate change, landscape, the greenhouse effect, climate, and weather compared with, at less than $50 \%$, the minimum average temperature, cold drops, and sunlight. Night-time irradiation and the albedo effect were practically mentioned by one teacher.

The results show that teachers identify some concepts as more important to explain climate change in class. Thanks to the analysis carried out with the questionnaire, we were able to demonstrate the confusion experienced by students about the climate and weather, the mistaken identification of the average temperature as a piece of data that explains the climate, or the confusion about the causes of climate change. Teachers attribute relative value to minimum average temperatures, night-time irradiation, the albedo effect of sunlight. Science, on the other hand, explains and draws links between climate change and the increase in night-time temperatures to explain global warming, one of the causes of climate change, as expressed in a report and evaluations by the Intergovernmental Panel on Climate Change (Houghton; Callander and Varney, 1992):

"Average warming over parts of the Northern Hemisphere mid-latitude continents has been found to be largely characterized by increases in minimum (night-time) rather than maximum (daytime) temperatures." (p. 7)

"A notable feature over considerable areas of the continental land masses of the Northern Hemisphere is that warming over the last few decades is primarily due to an increase in night-time rather than daytime temperatures." (p. 21).

The school geography curriculum in Spain prescribes the complexity of curricular content, in line with the cognitive level of the pupil, to be studied during primary and secondary education. Studying with a progression of knowledge is important. During primary education, the curriculum is based on the physical environment, studying the air, then the atmosphere, atmospheric phenomena, weather elements, measurements and recording, the difference between weather and climate, the characteristics of different climates, and explanations for climate change (Martínez and López, 2016). During secondary education, they expand on causal and complex thinking, physical and human geography,

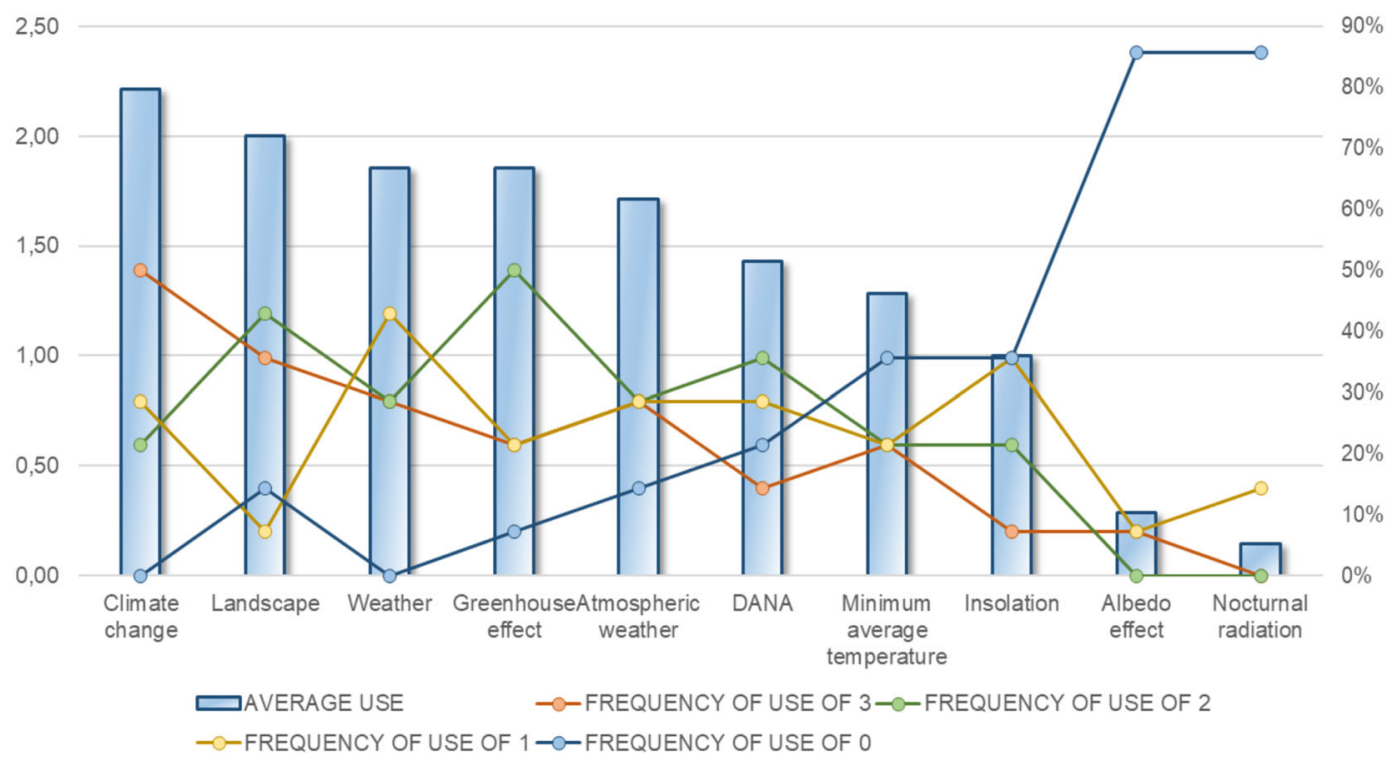

Fig. 5 Average use of climate change-related concepts. The graph bars show how teachers make use of these concepts. The frequency of use of these concepts, represented by colors, shows the percentage of use of each notion by teachers on a scale from 0 (never) to 3 (very frequently). 
and ecology from an analytical and later scalar perspective (Romero, 2010). Here lies the problem in properly understanding knowledge development processes on the topic of the climate. The teachers we interviewed mentioned this when they identified students' learning difficulties, identifying their lack of basic training, their idealization of concepts, or the discontinuity in the curricular development of the topic. However, this contrasts with how the teachers evaluated basic concepts used to explain the climate, which is more or less the same as those found in the textbooks, related to the curriculum, rather than those necessary for a comprehensive causal explanation, such as that of climate change. As such, sunlight is only valued by one of the teachers interviewed and used very little. In Ontinyent itself, data over the last 30 years reveals the progressive increase in annual temperatures (Souto, 2018b), which is not caused so much by sunlightthe same percentage of sunlight hours at certain times of the day is maintained-but rather by night-time irradiation. This concept was only mentioned by two teachers who use it very little.

As we can see, teachers mainly follow the topics in the curriculum as embodied in the textbooks, with the exception of the local reference to the Clariano river. They agree on the importance of this element of the landscape and understanding the significance of its dynamic relationship with the climate. The teachers observe the difficulty students have when studying the climate without leaving the classroom and speak of the need for more commensurate strategies. However, they maintain school traditions and routines, the use of the textbook, and standard curricular content.

\section{Conclusions}

The conclusions of the statistical study we carried out confirm the representativeness of the sample, while the analysis of responses verifies the substantiality of the surveyed population in tracking certain stereotypes in the "practical sense" (Domingos and Diniz, 2019) and the mechanic reproduction of climate and landscape concepts.

The results endorse the use of "practical sense" ideas ${ }^{21}$ when it comes to everyday explanations regarding the climate, climate change, and its relationship with the landscape. We expected to explain the traditional method of learning about the climate, conditioned by students' social representations. In this way, we concluded that the mistaken stereotypes and perceptions of a part of the academic population in primary, secondary, and baccalaureate, as well as higher education, are related with the assumption of "common sense", derived from an everyday practical sense, to which authority is granted when "the facts" are reflected in social communication media.

The study revealed that students' conceptual and stereotypical errors in the different educational stages vary according to the type (climate, weather, climate change, landscape) and stage (primary, secondary, university). They are persistent and continuous, given that they are repeated and appear anchored in the ideas and knowledge development of students regarding the problems and the study of the climate throughout their education.

We highlight the continuity regarding the manner of reasoning, although representations of abstract thinking are distinguished among secondary school and university students. In these stages, representations of concrete thinking, characteristic of lower cognitive levels and stages, are considered in the school curriculum for the teaching of the climate (Martínez and Olcina, 2019).

In the mind maps drawn by students about the climate and learning about the climate, we ascertained that the media and education are the most important factors in the development of knowledge among students. As regards the first, the influence of the internet and digital social communication media grows every day on students as a source of information, whilst other traditional sources of learning and knowledge such as school and family fall behind. As regards teaching, we highlight the role of the teacher in classes: how they teach, the obstacles of the school system, methodology, and the selection of conceptual aspects, procedures, and attitudes which predispose a certain education of the climate, its materialization on the landscape and the evidence of climate change.

Ultimately, the representativeness of the study helps us decipher one of the initial conjectures of this research: "stereotypes and conceptual errors about the climate and landscape are repeated in different statistical demographic cohorts". This means that the educational system reinforces the ideas derived from common sense and those who transform these stereotypes into alternative arguments as a result of academic education (basic and university) are scarce.

In terms of the students and given the considerable degree of confusion between the weather and climate or about the causes of climate change in the educational stages, we showed how social representations have had an impact on children, teenagers, and young adults developing their knowledge about the climate and landscape, influenced more by the presence of vulgar theories on the topic than by the understanding and application of school concepts.

As regards the teachers, we showed how teachers' intentions for methodological change collide with difficulties in specific continuous professional development. The obstacles to developing different methodologies, resources, and innovative activities are not overcome by teacher training in order to provide comprehensive explanations about climate change to their students. The increase of the influence of the media on students' education about climate change facilitates students' development of knowledge about the climate and environmental changes filled with errors and stereotypes. Some situations cannot be compared or analyzed in a classroom environment, either due to a lack of time dedicated to these topics or due to the obstacles inferred by teaching practice, such as the absence of specific training.

Failing to contest these spontaneous conceptions and academic traditions and routines leads to academic concepts being overshadowed by an incomplete explanation of the climate, resulting in a partial explanation based on vulgar and superficial ideas.

\section{Data availability}

The article directly contains the data used to carry out the analysis pertinent to the study. If you are interested in the rest of the data gathered for the research, it can be made available by reasonable written request to the authors.

Received: 29 September 2020; Accepted: 25 February 2021; Published online: 26 March 2021

\section{Notes}

1 The Social(S) group is recognized by the University of Valencia as a research group, including teachers from the non-university educational system as collaborators. For more details on the educational background of the group, you can check http:// socialsuv.org/educacionsocioambiental/.

2 Accordingly, we can highlight the doctoral theses by Diana Santana, "School participation and environmental governance: an educational dialectic" and Diego García, "The social representation of the rural environment: an analysis of schoo geography”, both presented in 2019, alongside more than ten Master's theses developed between 2011 and 2019 which tackle the line of research related with Socio-environmental Education.

3 EcoRiba is a program local to Riba-roja de Túria in Valencia, Spain, which aims to showcase the landscape in order to invigorate the territory. It was presented to society 
in February 2016 and underpins all the objectives of this sustainable strategy for socio-environmental education.

4 This is what we call students who have obstacles and hindrances to achieving the objectives and basic skills set out in the school curriculum for a certain age. The book "La invisibilidad de las periferias escolares" [The invisibility of marginalised students] by J. García and X. Souto (2020) contains a compilation of a research project, thesis, and innovative educational proposals for use in classrooms by teachers who carry out this work with their students.

5 Group subsidiary dedicated to research and innovation in the education of history and geography at the University of Valencia, Socials group which refers to the understanding of social and environmental problems when teaching and learning about the climate and landscape. https://www.uv.es/uvweb/servicio-investigacion/es/ grupos-investigacion/grupo-1285949714098.html?p2=GIUV2015-217.

6 The work we referred to pertained to research carried out within the Research in Specific Didactics Doctoral Programme at the University of Valencia, in the line of research of Geography Didactics. Namely, the doctoral thesis entitled "Knowledge of the climate and landscape: from analysis to a teaching proposal".

7 The Educational Innovation Project, "teacher training entrenched in the environment from the perspective of school practice" by the Generalitat Valencia with the code UV-SFPIE-GER18-85040, was developed during the three academic years from 2016 to 2019 by teachers in Ontinyent and the Department of Experimental and Social Science Didactics at the University of Valencia. This facilitated relationship-building with teachers, schools, and local bodies which was a guarantee for the sample and data collection.

8 Data about the Ontinyent population from the year 2016 extracted from the 2019 municipal sheets which can be found on the Generalitat Valencia's Statistics Portal: http://www.pegv.gva.es/auto/scpd/web/FITXES/Fichas/46184.pdf.

9 Representations held by Kindergarten pupils were studied, but the explanation thereof is not reflected in the article, because it was a specific study of drawings.

10 Hereafter, we will use the term Secondary Education to refer to Compulsory Secondary Education.

11 For this article, pictorial representations were not analyzed.

12 Census data from the Valencian Statistics Institute (IVE).

13 The procedure to validate the questionnaire consisted of sending a first model of 84 questions so that the five experts could evaluate it. With the comments and assessment of each item, we have selected the most relevant questions to be able to analyze the students' learning results; an exchange of views that have been archived, but not published. 10 questions have been selected from these results in this article.

14 See note 8, an Educational Innovation Project created with the objective of both students and teachers improving the teaching and learning about the climate and local landscape.

15 See note 4 of this article.

16 IPCC is the acronym for the Intergovernmental Panel on Climate Change, made up of an international group of experts and part of the $\mathrm{UN}$, which generates periodical reports with studies and recommendations about climate change.

17 In the Community of Valencia, the Cefire is responsible for providing state-run courses for the continued professional development of teachers.

18 See previous note.

19 IGU is the acronym for the International Geographical Union.

20 Response received to the question regarding when and on what topic they take classes, given by a biology teacher from a public school which provides compulsory secondary education.

21 We follow the theories of Moisés Domingos regarding Pierre Bourdieu and Sergi Moscovici's ideas.

\section{References}

Alatorre-Frenk G, González-Gaudiano E, Bello O (2016) Representaciones Sociales sobre Cambio Climático. Un Acercamiento a sus Procesos de Construcción. Trayectorias año 18(43):73-92

Alfageme M, Miralles P, Monteagudo J (2010) Diseño y validación de un instrumento sobre evaluación de la geografía y la historia en educación secundaria. Enseñanza de las ciencias sociales 10:51-58. https://www.redalyc.org/pdf/ 3241/324127610007.pdf

Álvarez C, San Fabián JL (2012) La elección del estudio de caso en investigación educativa. Gazeta de Antropología 28 (1). Available in https:/www.ugr.es/ $\sim$ pwlac/G28_14Carmen_Alvarez-JoseLuis_SanFabian.html

Anderson L, Krathwohl D (2001) Una taxonomía para el aprendizaje, la enseñanza y la evaluación: una revisión de la taxonomía de los objetivos educativos de Bloom. Longman, Nueva York

Bajo M (2016) Representaciones sobre el paisaje en los futuros maestros/as de educación infantil y primaria. Un estudio de caso. Tesis inédita, Universidad de Salamanca. https://doi.org/10.14201/gredos.132799

Banchs M (2000) Aproximaciones procesuales y estructurales al estudio de las representaciones sociales. Papers on Social Representations. Textes sur représentations sociales 9:310-315. http://psr.iscte-iul.pt/index.php/PSR/ article/view/269
Biggs J, Tang C (2007) Teaching for Quality Learning at University. Open University Press, Nueva York

Bisquerra R (2009) Metodología de la investigación educativa. La Muralla, Madrid

Boon H (2014) Teachers and the communication of climate change science: a critical partnership in Australia. Procedia-Soc Behav Sci 116:1006-1010. https://doi.org/10.1016/j.sbspro.2014.01.336

Campo B (2014) Estrategias en el ámbito reeducativo para el aprendizaje de la geografía. In: Martínez R, Tonda E (eds) Nuevas perspectivas conceptuales y metodológicas para la educación geográfica (2). Grupo didáctica AGE, Murcia, p 121-137

Campo B (2019) Alfabetización geográfica, ciudadanía y educación geográfica en la formación del profesorado: elaborar tareas conectadas con el geoforo. In: Rodríguez L, Palacios N, Souto X M (eds) La construcción global de una enseñanza de los problemas sociales desde el geoforo iberoamericano. Nau Llibres, pp. 302-319

Campo B, Ciscar J, Souto XM (2014) Los espacios de la periferia escolar. Scripta Nova (18), 496(07). Universitat de Barcelona. https://revistes.ub.edu/index. php/ScriptaNova/article/view/14969

Campo B, Martínez M (2017) Estudio del clima y paisaje de Ontinyent: vincular investigación educativa con innovación escolar. In: Cámara A, Sinde E, Magro M (eds) Educaçao Geográfica na Modernidade Líquida, livro Atas do VIII Congresso Ibérico da Didática da Geografía. pp. 349-361

Campo B, García D, Souto XM (2019) Tradiciones escolares en la educación geográfica. Impugnar sus rutinas para favorecer la innovación. In: Parra D, Fuertes C (coords.) Reinterpretar la tradición transformar las prácticas. Tirant humanidades, València, pp. 45-72

Canet S, Morales A, Santana D (2018) Repensar las representaciones escolares desde la participación activa: estudio de casos en el segundo ciclo de educación infantil. In: Peris V, Parra D, Souto X M (coords), Repensamos la geografía e historia para la educación democrática. Nau Libres, València, pp. 89-101

Capel H (1981) Filosofía y Ciencia en la Geografía contemporánea. Barcanova, Barcelona

Capel H (1984) Geografía humana y ciencias sociales, Una perspectiva histórica Montesinos, Barcelona

Castells M (2006) La sociedad red: una visión global. Alianza editorial, Madrid

Castorina J, Barreiro A (2012) Los usos de las representaciones sociales en la investigación educativa. Educación, Lenguaje y Sociedad 9:15-40. https:// cerac.unlpam.edu.ar/index.php/els/article/view/1459

Cavalcanti L (2017) El análisis de la espacialidad y la comprensión del mundo: llave para la relevancia de la geografía escolar. In Sebastià R, Tonda E (coords) Enseñanza y aprendizaje de la geografía para el siglo XXI. Universidad de Alicante, Alicante, pp. 97-116

Chang CH, Pascua L (2016) Singapore students' misconceptions of climate change. Int Res Geogra Environm Educ 25(1):84-96. https://doi.org/10.1080/ 10382046.2015.1106206

Cohen L, Manion L (1990) Métodos de investigación educativa. La Muralla, Madrid

Council of Europa (2000) Convenio Europeo del Paisaje. https://www.mapa.gob.es/ es/desarrollo-rural/planes-y-estrategias/desarrollo-territorial/ 090471228005d489_tcm30-421583.pdf

Cruz L (2010) Diseño de un taller de meteorología para alumnos de educación secundaria. In: Marrón M (coord) Geografía, educación y formación del profesorado en el marco del espacio europeo de educación superior (I). Grupo de Didáctica de la AGE y Universidad Complutense de Madrid, Madrid, pp. 215-236

Dematteis G, Governa F (2005) Territorio y territorialidad en el desarrollo local. La contribución del modelo SLOT. Boletín de la A.G.E. 39:31-50. https://bage. age-geografia.es/ojs/index.php/bage/article/view/498/469

De Miguel R (2017) La producción científica reciente en didáctica de la geografía a través de las sociedades geográficas. Declaraciones, publicaciones y proyectos a nivel nacional e internacional. Documents d'Anàlisi Geogràfica 63/ 3:575-596. https://doi.org/10.5565/rev/dag.475

De Miguel R, Claudino S, Souto XM (2016) La utopía de la educación geográfica en las declaraciones internacionales de la UGI. XIV Coloquio Internacional de Geocrítica, Las utopías y la construcción de la sociedad del futuro. Universidad de Barcelona. Available in http://www.ub.edu/geocrit/xiv_demiguel_claudino.pdf

Del Rincón D, Arnal J, Latorre A et al. (1995) Técnicas de investigación en Ciencias Sociales. Madrid Dykinson, Madrid

Domingos M (2000) Habitus e representações sociais: questões para o estudo de identidades coletivas. In: Moreira A, Oliveira D (eds) Estudos interdisciplinares de representação social, 2nd edn., Goiânia, pp. 117-130

Domingos M, Diniz L (2019) Representações Sociais, Sens Pratique, Poder Simbólico e o Processo de Construção do Ser Docente. Arxius de Ciències socials 41:43-64

Elliot J (2000) La investigación-acción en educación, 4a edn. Morata, Madrid

Eurostat (2016) Economía sociedades digitales. https://ec.europa.eu/eurostat

García de la Vega A (2011) El paisaje: un desafío curricular y didáctico. Revista de Didácticas Específicas 4:1-19. https://revistas.uam.es/didacticasespecificas/ article/view/9187 
García de la Vega A (2014) El pensamiento crítico en el análisis e interpretación de las representaciones sociales del paisaje. In: Martínez R, Tonda E (eds) Nuevas perspectivas conceptuales y metodológicas para la educación geográfica. Asociación de Geógrafos Españoles, Murcia, pp. 93-108

García-Monteagudo D (2019) La representación social del medio rural: un análisis desde la geografía escolar. Tesis doctoral inédita. Universitat de València, València

García Pérez F (2002) Concepciones de los alumnos y conocimiento escolar. un estudio en el ámbito del medio urbano. Enseñanza de las Ciencias Sociales 1:17-25. https://www.raco.cat/index.php/EnsenanzaCS/article/view/126118

García Pérez F (2004) Las ideas de los alumnos y la enseñanza del medio urbano: la relevancia educativa de las concepciones sobre la ciudad. Díada, Sevilla

García Pérez F (2011) Geografía, problemas sociales y conocimiento escolar. Revista Anekumene 2:6-21. https://core.ac.uk/download/pdf/51389316.pdf

García Rubio J, Souto XM (2020) La invisibilidad de las periferias escolares. Diferencias personales y propuestas para mejorar el aprendizaje. Nau Llibres, València

Gil E (1994) Un ejemplo de uso de la asociación de palabras como técnica de recogida de datos sobre la representación del mundo social: la reconstrucción del campo semántico de los alumnos acerca del tema del tercer mundo. Didáctica de las ciencias experimentales y sociales 8:27-52. https://ojs.uv.es/ index.php/dces/article/view/3234/2845

Gil J (2003) La estadística en la investigación Educativa. Revista de Investigación Educativa 21(1):231-248. https://revistas.um.es/rie/article/view/99191

Goetz J, Lecompte M (1988) Etnografía y diseño cualitativo en investigación cualitativa. Morata, Madrid

Goldenberg S, Bengtsson H (2016) El gigante estadounidense del carbón financiaba a decenas de grupos que niegan el cambio climático, eldiario.es. https://www. eldiario.es/theguardian/compania-financiaba-grupos-nieganclimatico_0_526348057.html

González L (2018) Educar para la transformación Ecosocial. Fuhem, Madrid

González E, Maldonado A (2014) ¿Qué piensan, dicen y hacen los jóvenes universitarios sobre el cambio climático? Un estudio de representaciones sociales. Educar em revista 3:35-55. https://doi.org/10.1590/0104-4060.38106

Granados J (2017) La formulación de buenas preguntas en didáctica de la geografía. Documents d'Anàlisi Geogràfica 63/3:545-559. https://doi.org/10.5565/rev/ dag. 495

Graves N (1985) La enseñanza de la geografía (edn. orig. 1975). Visor, Madrid

Guerra P (2018) Clima y tiempo en Ontinyent. Universitat de València, València Hannoun H (1977) El niño conquista el medio. Kapelusz, Buenos Aires

Hart R (1993) La participación de los niños: de la participación simbólica a la participación auténtica. UNICEF. Innocenti Research Centre 4. https://www. unicef-irc.org/publications/538-la-participaci\%C3\%B3n-de-los-ni\%C3\% B1os-de-la-participaci\%C3\%B3n-simbolica-a-la-participaci\%C3\%B3n.html

Heras F (2015) Representaciones sociales del cambio climático en España: aportes para la comunicación. Tesis inédita. Universidad Autónoma de MadridUAM

Horno E (1937) Methods of instruction in the social studies. Charles Scribner's Sons, New York

Houghton J, Callander B, Varney S (eds) (1992) Climate Change 1992. The Supplementary Report to IPCC Scientific Assessment, Cambridge, University Press, Intergovernmental Panel on Climate Change 1992. https://www.ipcc.ch/ site/assets/uploads/2018/05/ipcc_wg_I_1992_suppl_report_full_report.pdf

IPCC (2013). 50 Informe IPCC. Available in https://archive.ipcc.ch/report/ar5/wg1/ index_es.shtml

IPCC (2014). Cambio climático 2014, mitigación del cambio climático. https:// www.ipcc.ch/site/assets/uploads/2018/03/WG3AR5_SPM_brochure_es-1.pdf

IPCC (2019). Informe Especial Cambio climático y Tierra. https://www.ipcc.ch/ $\mathrm{srccl} /$

Jaén M, Barbudo P (2010) Evolución de las percepciones medioambientales de los alumnos de Educación Secundaria en un curso académico. Revista Eureka sobre Enseñanza y Divulgación de las Ciencias 7:247-259. https://www. redalyc.org/pdf/920/92013009008.pdf

Jodelet D (1991) Representación Social: Un área en expansión. In: Paez D (ed) Sida: Imagen y Prevención. Ed. Fundamentos, Madrid

Kindelan A (2013) Percepción, información y comunicación del cambio climático: conocimiento en estudiantes universitarios. Tesis inédita, Universidad de Las Palmas de Gran Canaria. https://accedacris.ulpgc.es/handle/10553/10738

Kicher P, Fox E (2019) Y vimos cambiar las estaciones. Cómo afrontar el cambio climático en seis escenas. Errata naturae, Madrid

Liceras A (2000) Tratamiento de las dificultades de aprendizaje en Ciencias Sociales. Grupo Editorial Universitario, Granada

Martín-Vide J (2009) Diez verdades y diez mentiras en relación al cambio climático. Enseñanza de las Ciencias de la Tierra 17(2):120-127

Martínez R, López J (2016) La enseñanza de la climatología en los manuales escolares de ciencias sociales en Educación Primaria. In: Sebastiá R, Tonda E (eds) La investigación e innovación en la enseñanza de la Geografía. Universidad de Alicante, San Vicente del Raspeig, pp. 245-258
Martínez L, Olcina J (2019) La enseñanza escolar del tiempo atmosférico y del clima en España: currículo educativo y propuestas didácticas. Anales de Geografía 39(1):125-148. https://doi.org/10.5209/AGUC.64680

Maslin M (2019) 5 falsos mitos sobre el cambio climático. National Geographic España. https://www.nationalgeographic.com.es/ciencia/5-falsos-mitos-sobrecambio-climatico_14760/1

Miles M, Huberman A (1994) Data management and analysis methods. In: Denzin Lincoln (eds) Handbook of cualitative research. Sage Publication, Londres

Morales AJ, García F (2016) EcoRiba: plan de dinamización de Riba-roja de Túria a través del paisaje. In: R Calvo, Bou M, Portets J (coords), Desarrollo local sostenible y empleo verde, Neopàtria, València, pp. 133-144

Morales AJ (2017) Educación y territorio ¿¿Un binomio indisociable? La experiencia de EcoRiba. GeocritiQ. Plataforma digital iberoamericana para la difusión del trabajo científico. Universitat de Barcelona, Barcelona

Morales, A J (2018) EcoRiba una experiencia local de sensibilización ambiental. In Actas V Jornades d'Educació Ambiental, Centre d'Educació Ambiental de la Comunitat Valenciana (CEACV), València. Generalitat Valenciana. http:// www.agroambient.gva.es/documents/20550103/165908797/ VJORNADAS_EA_CEACV.pdf/463a0126-3dbc-45f5-89d6-bcca3f4elf7a

Morales AJ, Santana D, Sánchez T (2017) Identidades territoriales y educación ambiental. Del paisaje emocional al paisaje cultural. Íber Didáctica de las Ciencias Sociales. Geografía e Historia 89:12-16

Morote A, Campo B, Colomer J (2019) El conocimiento del cambio climático en los futuros docentes de Educación Primaria. Una Experiencia de conocimientos previos a partir de la enseñanza de las ciencias sociales. In: VV AA Libro de actas del XXVI Congreso AGE, Crisis y espacios de oportunidad. Retos para la Geografía. AGE y Universitat de València, pp. 106-120

Morin E (1990) Introducción al pensamiento complejo. Gedisa, Madrid

Moscovici S (1961) La psychanalyse, son image, son public. Presses Universitaires de France, Paris

Olcina J (2017) La enseñanza del tiempo atmosférico y del clima en los niveles educativos no universitarios: propuestas didácticas. In. Sebastiá $\mathrm{R}$, Tonda $\mathrm{E}$ (dirs.) Enseñanza y aprendizaje de la Geografía para el siglo XXI. Universidad de Alicante, Alicante, pp. 119-148

Olcina J, Martín J (1999) La influencia del clima en la historia. Arco libros, Madrid Otzen T, Manterola C (2017) Técnicas de Muestreo sobre una Población a Estudio. Int J Morphol 35(1):227-232. https://doi.org/10.4067/S0717-95022017000100037

Rekalde I, García J (2015) El aprendizaje basado en proyectos: un constante desafío. Innovación Educativa 25:219-234. https://doi.org/10.15304/ie.25.2304

Reigota M (2001) Meio ambiente e representação social. Cortez Editora, São Paulo

Rodríguez G, Gil J, García E (1996) Métodos de investigación cualitativa. Aljibe, Málaga

Rodríguez C, Lorenzo O, Herrera L (2005) Teoría y práctica del análisis de datos cualitativos. Proceso general y criterios de calidad Revista Internacional de Ciencias Sociales y Humanidades. SOCIOTAM 15(2):133-154

Romero A (2010) La enseñanza de la Climatología en Secundaria y Bachillerato: propuesta metodológica. In: Marrón M (Coord.) Geografía, educación y formación del profesorado en el marco del espacio europeo de educación superior,vol. II. Madrid, Grupo de Didáctica de la AGE y Universidad Complutense de Madrid, Madrid, pp. 747-764

Sancho J, Hernández F (2004) ¿Por qué no ha fructificado la propuesta de profesor como investigador? $\mathrm{Y}$ algunas propuestas para resistir a un presente nostálgico. Educar 34:39-51

Santana D, Morales A, Souto XM (2014) Las representaciones sociales del paisaje en los trabajos de campo en Educación Primaria. In:, Mártínez R, Tonda E (eds) Nuevas perspectivas conceptuales y metodológicas para la educación geográfica. Asociación de Geógrafos Españoles, Murcia, Vol. 1, pp. 167-182

Santana D (2019) Participación escolar y gestión ambiental: una dialéctica educativa. Tesis inédita. Universidad de València, València

Santiago J (2008) La enseñanza de la geografía y la educación ambiental desde la perspectiva de los docentes. Revista de Teoría y Didáctica de las Ciencias Sociales 13:147-169

Saraiva J (2007) Habitus docente e representaçao social do "ensinar geografia" na Educaçao Básica de Teresina-Piauí. Programa Posgraduaçao em Educaçao. Universida de Federal Río Grande do Norte, Natal, https://repositorio.ufrn. br/jspui/bitstream/123456789/14138/1/JoseliaSS.pdf

Sebastiá R, Tonda, E (2017) Aprendizajes esenciales y formación docente en la enseñanza de la geografía. In: Camara A, Sande E, Magro M (Coords) Educaçao Geográfica na Modernidade Lìquida. Platano Editora, Santa Marta de Corroios, pp. 25-43

Souto XM (2011) La construcción de saber escolar en la sociedad de las comunicaciones. Investigación en la escuela 75:7-19. https://doi.org/10.12795/IE.2011.i75.01

Souto XM (2013) Investigación e innovación educativa: el caso de la Geografía escolar. Scripta Nova, Revista Electrónica de Geografía y Ciencias Sociales. Universidad de Barcelona, Barcelona

Souto XM (2016) La investigación cualitativa y la innovación didáctica en geografía. El trabajo cualitativo como recurso didáctico en geografía. Actas XI Congreso Nacional Didáctica de la Geografía. In: Alanis F et al. (eds) Nativos digitales y 
geografía en el siglo XXI: Educación geográfica y sistemas de aprendizaje. Grupo Didáctica de la AGE y Universidad Pablo de Olavide, Sevilla, pp. 80-101

Souto XM (2018a) La geografía escolar: deseos institucionales y vivencias de aula. Boletín de la Asociación de Geógrafos Españoles 79:1-31. https://doi.org/ 10.21138/bage.2757

Souto XM (2018b) Prólogo. In: Guerra P (ed) Clima y tiempo en Ontinyent. Universitat de València, València

Souto XM, García D (2016) La geografía escolar ante el espejo de su representación social. Didáctica Geográfica 17:177-201

Stake R (1999) Investigación con estudio de casos. Ediciones Morata, Madrid

Stenhouse L (1975) An introduction to curriculum research and development. London Heinemann, London

Stenhouse L (1990) La investigación como base de la enseñanza. Morata, Madrid

Teppa S (2012) Investigación-Acción Participativa en la Praxis Pedagógica Diaria. Intervenir la práctica pedagógica para transformar la sociedad y lograr la evolución del docente-investigador. Editorial Académica Española, Madrid

Tonda E, Sebastiá R (2003) Las dificultades en el aprendizaje de los conceptos de tiempo atmosférico y clima: la elaboración e interpretación de climogramas. Revista de Educación de la Universidad de Granada 16:47-69

Valbuena M, Valverde J (2006) La climatología local. Procedimientos para su enseñanza aprendizaje. Didáctica Geográfica, 2. Época 8:93-108. https://didacticageografica. age-geografia.es//index.php/didacticageografica/article/view/84/83

UNEP (2019) Perspectivas del Medio Ambiente Mundial, GEO 6: Planeta sano, personas sanas, Nairobi. https://wedocs.unep.org/bitstream/handle/20.500.11822/ 27652/GEO6SPM_SP.pdf?sequence=68risAllowed $=\mathrm{y}$

United Nations (2015) Transformar nuestro mundo: la Agenda 2030 para el Desarrollo Sostenible. Código: A/RES/70/1. https://n9.cl/12ot

Wardle C, Nielsen K, Mantzarlis A, Jiménez C (2018) Seis puntos clave del informe sobre desinformación del Grupo de expertos de la Comisión Europea. eldiario.es. https://www.eldiario.es/tecnologia/desinformacionGrupo-expertos-Comision-Europea_0_749275859.html

\section{Acknowledgements}

This work is part of the project: The social representations of school content in the development of teaching skills, R\&D Projects on Knowledge Development and Scientific
Consolidation and System Technology $\mathrm{R}+\mathrm{D}+\mathrm{i}$ (Spanish Ministry of Science, Innovation and Universities), reference PGC2018-094491-B-C32, and co-financed with EU FEDER funds. This work was supported by the research project "The social representations of educational content in the development of teaching competencies" [PGC2018-094491-B-C32], funded by the Ministry of Science, Innovation, and Universities of Spain and co-funded by the ERDF.

\section{Competing interests}

The authors declare no competing interests.

\section{Additional information}

Correspondence and requests for materials should be addressed to B.C-P. or X.M.S-G

Reprints and permission information is available at http://www.nature.com/reprints

Publisher's note Springer Nature remains neutral with regard to jurisdictional claims in published maps and institutional affiliations.

\section{(c) (i)}

Open Access This article is licensed under a Creative Commons Attribution 4.0 International License, which permits use, sharing, adaptation, distribution and reproduction in any medium or format, as long as you give appropriate credit to the original author(s) and the source, provide a link to the Creative Commons license, and indicate if changes were made. The images or other third party material in this article are included in the article's Creative Commons license, unless indicated otherwise in a credit line to the material. If material is not included in the article's Creative Commons license and your intended use is not permitted by statutory regulation or exceeds the permitted use, you will need to obtain permission directly from the copyright holder. To view a copy of this license, visit http://creativecommons.org/ licenses/by/4.0/

(C) The Author(s) 2021 